\title{
Mobility and accessibility in historic cities
}

\author{
Carvalho, Ana Carla, Paschoalin, Rachel Filgueiras and Castañon, José Alberto ${ }^{1}$ \\ Department of Transportation, Federal University of Juiz de Fora, Engineering Faculty, Room 4156 Campu of \\ UFJF, Juiz de Fora, Minas Gerais, Brasil
}

\begin{abstract}
The historic cities of Brazil, despite its colonial structure, don't fail to go through transformations that affect contemporary cities, which is the main source of problems, leading to new approaches to urban issues such as mobility and accessibility. The uncontrolled growth of tourism in the historic cities can be considered as a big problem, because at the same time, they have committed to the conservation of its built heritage and demand control of the activities that occur in their areas without harm. Then, a permanent dialogue between conservatives and planners could be accomplished by joining the various sectoral policies. The study of urban mobility in historical sites was in fact the focus of this work because of their peculiarities, such as its specific characteristics of urban structure, morphology and occupation. In fact, the development of tourism in historic centers generates specific demands, such as adaptation to new uses of the houses, intensive movement of people and vehicles, illegal parking, among others. Beyond threatening the city preservation, does not provide mobility and accessibility to tourists, because these cities were not designed for the tourism conditions and needs of contemporary life. Characteristic features of Brazilian baroque cities, such as topography, the narrow streets, narrow or nonexistent sidewalks, steep turns and ramps strong, are not suitable for heavy vehicles, traffic and pedestrian circulation. Thus, studies concerning conservation urban integrated are aimed at an approach to interaction between historic preservation of the environment with the dynamic socio-economic of the local.
\end{abstract}

Keywords: Historic Cities, Tourism, Ergonomics, Mobility and Accessibility

\section{Introduction}

The historic cities of Brazil, despite its colonial structure, don't fail to go through transformations that affect contemporary cities, which is the main source of problems, leading to new approaches to urban issues such as mobility and accessibility. With expectations of prosperity in the tourism sector, the urban and social situation of these cities is getting worse because the sector's growth don't follow the development of its urban infrastructure.

It is understood that the city is not completely synchronous, the urban fabric, people's behavior, economic or social urban policies develop by different timelines. This fact explains the origin of problems related to the infrastructure of the historical cities. It can be considered from the history point of view that the theme of the city is within a more complex perspective, combining objective aspects as timing, form, uses and functions. This theme, in particular, questions the "stylistic" or temporal classifications mentioned, like the baroque city, based on matching a particular model or period 'frozen' in time (CARVALHO, 2009).

Mixtures of temporalities that historical cities show confirm their need for rehabilitation to the demands of contemporary life, because the new models of lifestyle and mobility are very different from those of the past (CAMAGNI; GIBELLI; RIGAMONTI, 2002). Cities are distinct in the presence of nuclei with specific characteristics, necessary of appreciation and simultaneously adaptation to different contexts those that formed the basis of their origin. In this context, notably the "historical center" clusters as in times past (medieval, Renaissance or Baroque), surviving in the cities (FURTADO; MACEDO, 2010).

The study of urban mobility in historical sites was in fact the focus of this work because of their peculiarities, such as its specific characteristics of urban structure, morphology and occupation, these periods that reflect socio-economic and technological

\footnotetext{
${ }^{1}$ Carvalho, A.C. - anacarlacarvalho.arq@gmail.com - Castañon, J.A.B. - jose.castanon@ufjf.edu.br
} 
development are distinct from other areas of the city. In general, the historical centers are configured for long blocks, narrow streets and irregular, building without side setbacks and homogeneous heights on the scale of the pedestrian (RAMOS; MAIA, 200?).

\section{Urban mobility and accessibility $x$ urban structure}

With regard to mobility and accessibility, it is critical to understand and conceptualize the theory and practice of the term historical center because of its amplitude in front of concept of a historical monument. In fact, there is a new concept for urban heritage, positioning the value of the object as part of a system, integrating the practice of usefulness to museologic essence. Thus, the appreciation of the historical center is much more than the requalification of public spaces and particular buildings, is also the appreciation of who's there and who goes to the historical center (FURTADO; MACEDO, 2010).

The integrated urban conservation has as approach the interaction of historical preservation and appreciation of the environment with the dynamic socio-economic location. The discussion of urban mobility and accessibility emerges as a key factor for integrating physical-territorial and socio-economic historical areas and for the preservation of their cultural heritage.

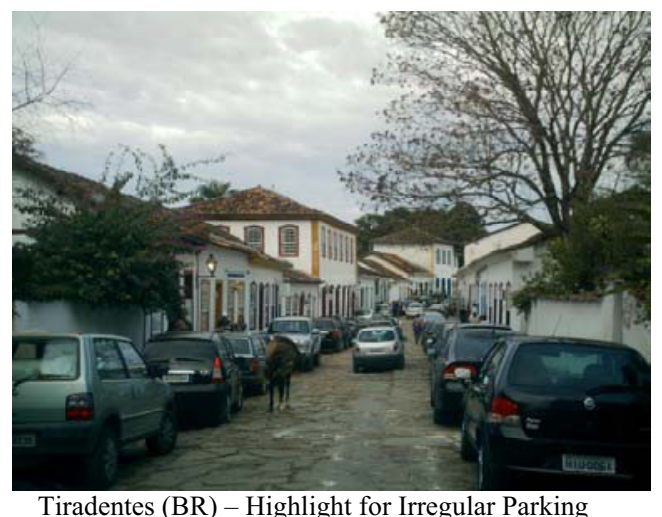

Source: Personal Collection

It is known that the tourism development in historical cities generates specific demands, such as adaptation to new uses of the houses, intensive movement of people and vehicles, illegal parking, among others. Beyond threatening the city preservation, does not provide mobility and accessibility to tourists, because these cities were not designed for the tourism conditions and needs of contemporary life. Despite the importance of ergonomics, in other words, people's comfort, this fact proves irrelevant to public administration.

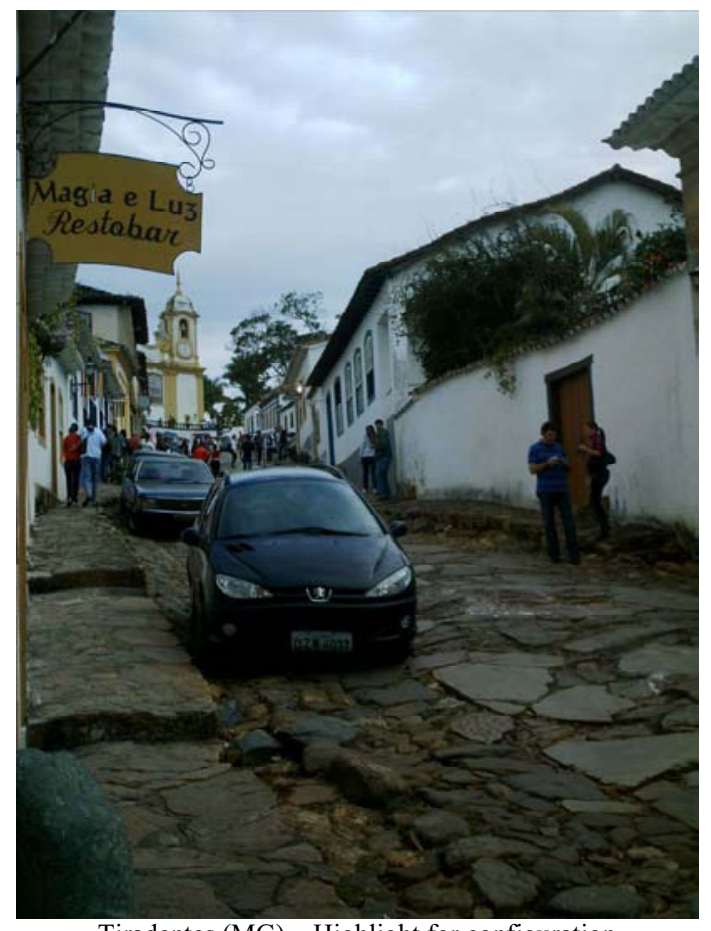

Tiradentes (MG) - Highlight for configuration the road and houses Source: Personal Collection

The uncontrolled growth of tourism in the historic cities can be considered as a big problem, because at the same time, they have committed to the conservation of its built heritage and demand control of the activities that occur in their areas without harm. This fact is inevitable but can be mitigated in accordance with well-developed technical procedures. In this case, the relationship between heritage policies and urban planning becomes very important.

A permanent dialogue between conservatives and planners could be accomplished by joining the various sectoral policies. Thus, it is considered that the policies concerning the transport and a better distribution of the centers of urban activity can have significant impact on preserving the architectural heritage of the city and ergonomics (CASTRIOTA et al, 2010). Well as understanding that collective identity and memory are essential values that must be present in any urban planning task (LAPA; MELO, 2007).

Characteristic features of baroque Brazilian cities, such as the hilly, narrow streets, narrow or nonexistent sidewalks, steep turns and strong ramps are not 
ent sidewalks, steep turns and strong ramps are not suitable for heavy vehicles, traffic and pedestrian circulation. There is still a lack of traffic signs, which is a factor of extreme importance considering the ergonomic principles (WERNECK, 2002 apud SANDOVAL, 2009). So it's essential the extreme control of these poor impacts in order to reduce them to the fullest, through the development, monitoring, planning and constant study.

\section{Notes}

The implementation of some actions among government entities at the municipal, state and federal levels are important to be performed on all the historical cities, to the right preservation of these (GRAMMONT, 2006). A relevant initiative is the correspondence of the practice of urban planning with public participation, this can indicate areas of growth for the city at the municipal level and in the short term. Another need is an existing policy to promote the preservation that includes a broad and rigorous program of heritage education. It is also essential in the context of urban planning, to take necessary measures as the implementation of a sort of traffic project.

It is considered that preservation can not be dissociated from the modernization of cities, dynamic for excellence. Thus, it is important integrating conservation with urban and regional planning. It is recognized that the protection of historical heritage in cities should be the goal of urban and territorial planning, as well as, one should be aware that the municipalities are mainly responsible for conservation.

"Urban development depends on a large set of economic, social, political and cultural factors, as well on concrete policies adopted by the Government, the private sector, the citizens in general, and organized society (LAPA; MELO, 2007)".

To sum up, this work emphasizes the studies to problems of mobility and accessibility in cities tumbled, due to its features discoursed on the text. It aims to find alternatives to this fact by analyzing their physical growth disordered, the lack of attention of the competent bodies and the great encouragement to tourism on the rise. It is understood that the city takes place at different moments in time, hence the beauty and complexity of this, because the urban fabric, the behavior of the townspeople, the politics of urban planning develop in different timelines. Hence the concern to meet the ergonomic comfort of the people in these cities because all its complexity has already explored.

\section{References}

[1] Camagni, R.; Gibelli, M. C., RigamontiI, P. (2002) Urban Mobility and Urban Form: The Social and Environmental Costs of Different Patterns of Urban Expansion. Ecological Economics 40 (2002) 199-216. Milan, Italy.

[2] Carvalho, A. C. (2009) Pousada em Tiradentes: uma edificação marcando seu presente, num histórico passado colonial. Juiz de Fora: UFJF

[3] Castriota, L. B et al (2010) PAC Cidades Históricas oportunidade para a conservação integrada?. Locus: revista de história, v. 16, n. 2 p. 93-117. Juiz de Fora: UFJF.

[4] Furtado, G.; Macedo, R. (200?) Reabilitação urbana e intervenção em centros históricos: alguns desafios e evolução de paradigmas em Portugal. Porto: Faculdade de Arquitetura da Universidade do Porto.

[5] Grammont, A. M. (2006) Ouro Preto: problemas de um patrimônio histórico no início do século XXI. Turismo - Visão e Ação - vol. 8 - n.3 p. 455-467 set. /dez. Itajaí: UNIVALI.

[6] Instituto do Patrimônio Artístico e Nacional. Cartas Patrimoniais. Disponível em: $\quad<$ http://www. http://portal.iphan.gov.br>. Acesso em: setembro 2011.

[7] Lapa, T.; Melo, R. (2007) Interventions in historic areas, mobility and urban conservation: the case study of Bairro do Recife District. City \& Time 2 (3): 4. [online] URL: http://www.ct.ceci-br.org.

[8] LE CORBUSIER (1993) Carta de Atenas. Tradução Rebeca Sherer. São Paulo: EDUSP.

[9] Maia, F. A. (2003) Direito à memória: o patrimônio histórico, artístico e cultural e o poder econômico. Movendo Idéias, v8, n.13, p. 39-42, junho. Belém: UNAMA.

[10] Oliveira, F. V. (2003) Capacidade de carga nas cidades históricas. Campinas: Papirus.

[11]Ramos, E. H. de O.; Maia, M. L. (200?) Sítios Históricos Urbanos e seus deslocamentos. Estudo de Caso: sítio histórico do município de Olinda/PE. Recife: Universidade Federal de Pernambuco.

[12] Sandoval, C. G.; Arruda, J. S.; Santos, N. C. (2009) Ouro Preto: Impactos da atividade turística em uma cidade tombada. Revista Itinerarium v.2. Rio de Janeiro: UNIRIO.

[13] Soares, G. M. (2006) Os Impactos do Turismo em Cidades Históricas - Estudo de Caso Tiradentes MG. IV SeminTUR Seminário de Pesquisa em Turismo do MERCOSUL, julho. Caxias do Sul: Universidade de Caxias do Sul. 